\title{
Dial behavioral responses of Metamysidopsis elongata atlantica (Crustacea, Mysida) to gradients of salinity and temperature
}

\author{
Andréa M. da S. Gama ${ }^{1}$, Danilo Calazans ${ }^{2} \&$ Nelson F. Fontoura ${ }^{1}$ \\ 1. Faculdade de Biociências, Pontifícia Universidade Católica do Rio Grande do Sul, Av. Ipiranga 6681, Caixa Postal 1429, 90.619-900 \\ Porto Alegre, RS, Brazil. (andreamgama@gmail.com) \\ 2. Laboratório de Crustáceos Decápodes, Departamento de Oceanografia, Fundação Universidade Federal do Rio Grande, Caixa Postal \\ 474, 96.201-900 Rio Grande, RS, Brazil.
}

\begin{abstract}
Metamysidopsis atlantica elongata (Bascescu, 1968) is a common mysid in the surf zone of sandy beaches from the state of Rio Grande do Sul, Brazil, where it is frequently recorded forming dense aggregations. Trough laboratory trials, behavioral responses to salinity $(10,20,25,28,30,40$ e 45$)$, temperature $\left(10,15,20,30 \pm 1^{\circ} \mathrm{C}\right)$ and light (yes/no) were tested using adult males, adult females and juveniles. Although there was no response to temperature, the species showed clear response to salinity and light. In the presence of light, organisms remained in the bottom of the aquaria, but moved to surface when bottom salinities were increased. In the absence of light, adults moved to the surface. However, juveniles moved down to or remained on the bottom, maybe as a response to avoid adult predation.
\end{abstract}

KEYWORDS. Mysids, behavior, light, predation.

\begin{abstract}
RESUMO. Respostas do comportamento nictimeral de Metamysidopsis elongata atlantica (Crustacea, Mysida) a gradientes de salinidade e temperatura. Metamysidopsis elongata atlantica (Bascescu, 1968) é um misídeo comum na zona de arrebentação de praias arenosas do Rio Grande do Sul, Brasil, onde aparece constantemente formando densas manchas. Em laboratório, respostas comportamentais a salinidade $(10,20,25,28,30,40$ e 45$)$, temperatura $\left(10,15,20,30 \pm 1^{\circ} \mathrm{C}\right)$ e luz (sim/não) foram testadas usando machos adultos, fêmeas adultas e juvenis. Embora não tenha ocorrido resposta à temperatura, as espécies mostraram respostas claras à salinidade e luz. Na presença de luz, os organismos permaneceram no fundo do aquário, porém se moveram para a superfície quando as salinidades do fundo aumentaram. Na ausência de luz, os adultos se moveram para a superfície do aquário. No entanto, os juvenis desceram ou se mantiveram no fundo, provavelmente como uma resposta para evitar a predação dos adultos.
\end{abstract}

PALAVRAS-CHAVE. Misídeos, comportamento, luminosidade, predação.

Metamysidopsis elongata atlantica (Bascescu, 1968) is a frequent and abundant mysid, observed in neritic zones of the Atlantic Ocean, frequently observed in dense patches (MaUChline, 1980). This species was recorded in southeastern Brazil (Cananéia, state of São Paulo) (Almeida-PRADO, 1974), as well as inhabiting the surf zone of sandy beaches (GAMA \& ZAMBONI, 1999; GAMA et al., 2002; GAMA et al., 2006) and the surrounding area of Patos Lagoon Estuary in the state of Rio Grande do Sul (southern Brazil) (LoPEs et al., 2006).

The high biomass of the mysid shrimps in estuaries and sandy beaches suggest that they play an important role in the trophic web of these ecosystems, being predated by commercially important fish and crustacean that use these habitats as nursery and spawning grounds (LASIAK, 1981; WoOLDRIDGE, 1983; LASIAK \& MCLACHLAN, 1987; McLachlan, 1990; Brown \& McLachlan, 1990; Du Preez et al., 1990; Jerling \& Wooldridge, 1995; CALLiari et al., 2001, 2007).

According to SCHLACHER \& WOOLDRIDGe (1994), pelagic invertebrates in estuarine systems present different mechanisms to control their relative position: reproductive compensation to compensate animal loss to ocean waters, and adaptative behavior, changing responses to hydrodynamic process. Mysids, as part of hyperbenthos are also subject to these mechanisms.

The reproductive compensation can be observed on breeding females, which are very fecund and keep the offspring in the marsupium after hatch, increasing the chances of survival (MAUCHLINE, 1980). The adaptative behavior is characterized by changes in the swimming activity according to tide or currents (WARMAN et al., 1991; HougH \& NAYLOR, 1992).

Several studies have been performed on mysids behavior and the focus has turned to their swimming behavior during the last decades (STEVEN, 1961; Clutter, 1969; Mauchline, 1971; WitTMANN, 1977; O'Brien et al., 1986; ROAST et al., 1998).

Vertical migrations of mysids in the water column may be diurnal, nocturnal or diel, being related to age, gender, environmental conditions and season (Mauchline, 1980; Willians \& Collins, 1984; Moffat \& Jones, 1993; SChlacher \& WoOldRige, 1994; Caliari et al., 2007). In general, adult mysids remain close to bottom during the day (ViherLouto \& ViItASALO, 2001; ScharF \& Koschel, 2004; TAKAHASHI et al., 2004; ANOKHINA, 2005) and migrate to surface during the night, where different species feed on phytoplankton, floating organic matter as well as on other zooplaktonic organisms (AlLEN, 1982; McLachlan, 1983; AstTHORSSON \& RALPH, 1984; JeRLING \& WoOdLDRIDGE, 1995; ViITASALO \& RaUtio, 1998).

The vertical diel migration occurs as a behavioral responses to food availability and to avoid predation (Clutter, 1967; Hampel et al., 2003). Additionally, other physical factors may influence migration of mysids, such as bottom type, reproduction (Hesthagen, 1973; MAUCHLine, 1980), ontogenetic development (Mauchline, 1980; TAKAHASHI \& KAWAGUCHI, 1997) as well as water temperature and salinity (Willians \& ColLins, 1984; MofFat \& Jones, 1993; CAlliari et al., 2001; PASTORINo et al., 2003).

Regarding to salinity, mysids present a clear preference for a specific range of values in laboratory 
experiments (BhATTACHARYA, 1982; LuQue et al., 1992; Cervino et al., 1996; Chung, 2001; Signoret \& Brailovsky, 2004) or in natural conditions (GROSS, 1957; PEZZACK \& Corey, 1982; Buskey, 1998; Miller, 2003). The effect of temperature as a driving factor related to vertical migrations of Mysis mixta Lilljeborg, 1852 was less significant than light intensity (RUDSTAM et al., 1989).

Data concerning $M$. e. atlantica suggest that the species can tolerate a wide range of salinity (12-45) as well as temperature $\left(11-28^{\circ} \mathrm{C}\right)$ (GAMA \& ZAMBONI, 1999). The present work attempts to identify the behavioral responses of $M$. e. atlantica to salinity and temperature under laboratory conditions, testing the role of these parameters on vertical migration related habitat occupation.

\section{MATERIAL AND METHODS}

Sampling and rearing of mysids. Individuals of $M$. e. atlantica were collected from the Cassino beach (state of Rio Grande do Sul, Brazil), in an area between the West Breakwater $\left(32^{\circ} 09^{\prime} \mathrm{S}, 52^{\circ} 06^{\prime} \mathrm{W}\right)$ and the shipwreck Altair, which is located $20 \mathrm{~km}$ southwards $\left(32^{\circ} 17^{\prime} \mathrm{S}, 52^{\circ} 15^{\prime} \mathrm{W}\right)$. Samples were obtained in January, February, November and December, 2006 as well as in January and February 2007. The individuals were sampled by using a cylindricalconical plankton net ( $2.5 \mathrm{~m}$ long, $0.60 \mathrm{~m}$ wide; mesh size of $300 \mu \mathrm{m}$ ) horizontally towed during 3 minutes in depths between $0.5 \mathrm{~m}$ and $1.5 \mathrm{~m}$.

Tows were performed up current in the surf zone always parallel to the beach line. A termosalinometer was used to obtain temperature and salinity measures during sampling procedure. After collection, individuals were transferred to 201 containers with artificial aeration and immediately transported to laboratory.

Metamysidopsis e. atlantica individuals were separated from the other planktonic animals by using a wide mouth pipette $(0.7 \mathrm{~cm}$ wide, $13 \mathrm{~cm}$ long) and transferred to 101 plastic containers filled with filtered salt water at the same salinity as observed during sampling. The organisms were kept under standardized photoperiod of 12L:12D, with fluorescent light and fed with Artemia sp., according to the protocol developed by GAMA \& ZAMBONI (1999).

Acclimatizing. The organisms used in the tests were divided in three different groups of 100 individuals each: male $(1.4 \mathrm{~mm}$ of carapace length), female $(1.6 \mathrm{~mm}$ of carapace length and visible masupiun) and juvenile $(<1.1$ mm of carapace length) and kept in 51 containers with the same salinity recorded during the sampling. To perform the tests salinity was increased or reduced in a rate of 5 parts at each 4 hours until achieve the desired salt concentration for each test. The acclimatizing to temperature followed the same procedure. At each 4 hours the temperature was reduced or increased in $5^{\circ} \mathrm{C} \pm 1^{\circ} \mathrm{C}$, until it was equalized with the room temperature where the tests were performed. The acclimatizing time was 24 hours.

The salinities of 10,20 and 25 were obtained through dilution with distilled water and salinities of 40 and 45 by adding the marine salt Red Sea. Salinities of 28 and 30 were obtained during the sampling procedure. The different temperatures used were obtained by keeping the containers in rooms with temperatures varying from 20 to $30 \pm 1^{\circ} \mathrm{C}$. The temperatures of 10 and $151^{\circ} \mathrm{C}$ were obtained by adding marine water cooled in the freezer.

Tests. To test possible behavioral responses of $M$. $e$. atlantica according to gradients of temperature and salinity, it was considered the assessment of tolerance to environmental parameters performed by GAMA \& ZAMBONI (1999), who verified a survivorship up to $80 \%$ in salinities between 15 and 35 .

To perform laboratory tests, a 401 container was used (Fig. 1). The test areas were designed as surface (1) and the bottom (2). These areas were vertically divided by a glass sheet (3), with a slide through which, a horizontal sheet was inserted or removed (4), physically dividing surface and bottom test areas.

In attempt to remove decisions based on gravitational and light factors, combinations of temperature and salinity were tested with animals inhabiting either the surface or bottom zones of the container.

The combinations of temperature and salinity were tested in the presence of room light and under dark conditions, in attempt to identify different responses. The mysid activities and behavioral alterations were recorded with a digital video camera. The response to salinity and temperature gradients was performed by first filling the area 2 (bottom) with water in the desired temperature/salinity. Then, the sheet 4 was moved to cover the entire area 2 , in such a way to fill the area 1 (surface) with water at the desired conditions of salinity and temperature for the test.

The horizontal sheet was carefully removed to minimize any disturbance concerning the environmental gradient. A total of 20 individuals previously acclimated was introduced into the area 1 (surface) or area 2 (bottom). After 15 minutes, the horizontal sheet (4) was moved to stop vertical migration, and the number of individuals in each area was counted. After each test, individuals were returned to the acclimatizing containers and to the natural environment afterwards.

All the tests were performed by using replicates (three for each condition) with groups of 20 males, 20 females and 20 juveniles separately tested. Each test lasted 15 minutes. All the salinity tests (T1-T15; Tab. I) were performed under the same temperature $\left(25 \pm 1^{\circ} \mathrm{C}\right)$. The tests from T1 to T10 were performed under the room light and the tests from T11 to T15 were performed under dark conditions. The salinities tested were 10, 20, 25, 28, 30,40 e 45 . The temperature tests (T15 to T19; Tab. II) of

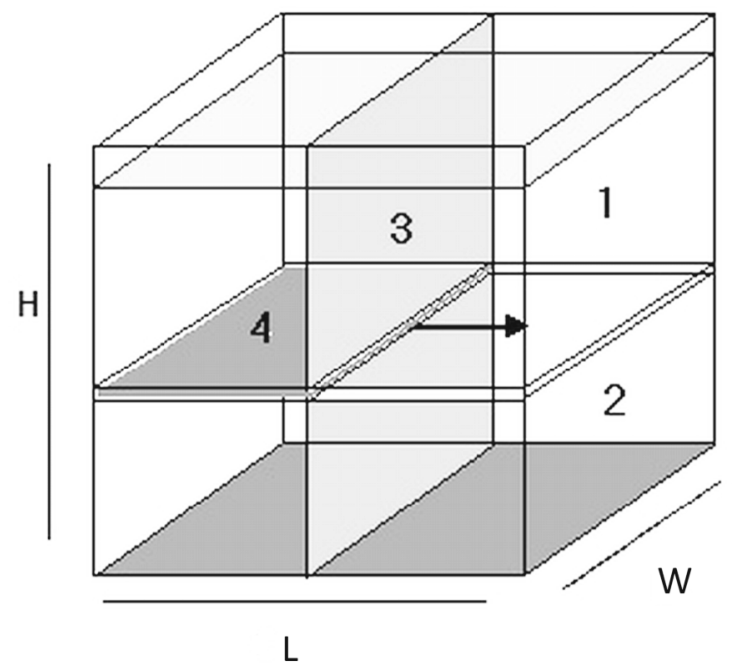

Figure 1. Container used on behavioral tests. 1, surface area; 2 , bottom area; 3, vertical sheet; 4, horizontal sheet; $\mathrm{H}$, height (30 $\mathrm{cm})$; L, lenght $(40 \mathrm{~cm}) ; \mathrm{W}$, width $(30 \mathrm{~cm})$. 
Table I. Salinity tests (T1 to T15) of females, males and juveniles of Metamysidopsis elongata atlantica (Bascescu, 1968) $(\mathrm{n}=20)$ performed at the temperature of $25 \pm 1^{\circ} \mathrm{C}$. The tests from $\mathrm{T} 1$ to T10 were performed under room light and from T11 to T15 under dark conditions, where the number with the asterisk represents the position where the organisms were released and the grey area the salinity at acclimatizing.

\begin{tabular}{ccc}
\hline & \multicolumn{2}{c}{ Salinity } \\
\cline { 2 - 3 } Tests & Surface & Bottom \\
\hline T 1 & $28^{*}$ & 28 \\
T 2 & $30^{*}$ & 30 \\
T3 & $20^{*}$ & 40 \\
T 4 & $30^{*}$ & 45 \\
T 5 & 30 & $45^{*}$ \\
T6 & $10^{*}$ & 20 \\
T $~$ & $20^{*}$ & 30 \\
T 8 & 20 & $30^{*}$ \\
T & $25^{*}$ & 30 \\
T1 & 25 & $30^{*}$ \\
T1 1 & $28^{*}$ & 28 \\
T12 & $20^{*}$ & 30 \\
T13 & 20 & $30^{*}$ \\
T1 & $25^{*}$ & 30 \\
T15 & 25 & $30^{*}$ \\
\hline
\end{tabular}

Table II. Temperature tests (T16 to T19) of females, males and juveniles of Metamysidopsis elongata atlantica (Bascescu, 1968) $(n=20)$ performed under salinities of $20 \pm 1$ under room light, where the number with the asterisk represents the position where the organisms were released and the grey area the temperature at acclimatizing.

\begin{tabular}{ccc}
\hline & \multicolumn{2}{c}{ Temperature $\left({ }^{\circ} \mathrm{C}\right)$} \\
\cline { 2 - 3 } Tests & Surface & Bottom \\
\hline T 16 & $30^{*}$ & 20 \\
T 17 & 30 & $20^{*}$ \\
T 18 & $20^{*}$ & 15 \\
T 19 & $20^{*}$ & 10 \\
\hline
\end{tabular}

M. e. atlantica were performed at a salinity of $20 \pm 1$ under room light in temperatures of $30,20,15$ e $10^{\circ} \mathrm{C}$.

The comparison of observed-expected frequencies was performed by using a Chi-square test. Considering the use of multiple tests, a Bonferroni correlation test to critical $\mathrm{p}$ values was performed.

\section{RESULTS}

The salinity range recorded in the environment during sampling varied from 28 and 30 and temperature between 24 e $25 \pm 1^{\circ} \mathrm{C}$. During the acclimatizing period, the mysids presented $100 \%$ survival after 96 hours, even when decrease or increase in temperature or salinity at each 4 hours were performed.

The recorded behavior in tests $\mathrm{T} 1$ and $\mathrm{T} 2$, with the same salinity either in the surface and bottom, was to stay at or migrate to the bottom of the container immediately after been released in the surface $(\mathrm{p}<0.001)$ (Tab. III). During the test T3, where a halocline structure was formed (20-40), it was observed that the organisms tried initially to move to the bottom, however they did not transposed the halocline barrier and therefore, were recorded in the surface after 15 minutes $(\mathrm{p}<0.001)$ (Tab. III).

In the test $\mathrm{T} 4$, with a halocline $30-45$, the organisms released in the surface also presented a trend to go down in the water column, however, they were recorded in the surface after identifying the higher salinities of the bottom ( $\mathrm{p}<0.001)$ (Tab. III). In the test T5, with the same salinity gradient (30-45), but with mysids released at the bottom

Table III. Salinity tests using females, males and juveniles of Metamysidopsis elongata atlantica (Bascescu, 1968) (n=20) performed at temperatures of $25 \pm 1^{\circ} \mathrm{C}$ under room light, where the number with the asterisk represents the place where individuals were released and the grey area is the acclimation salinity.

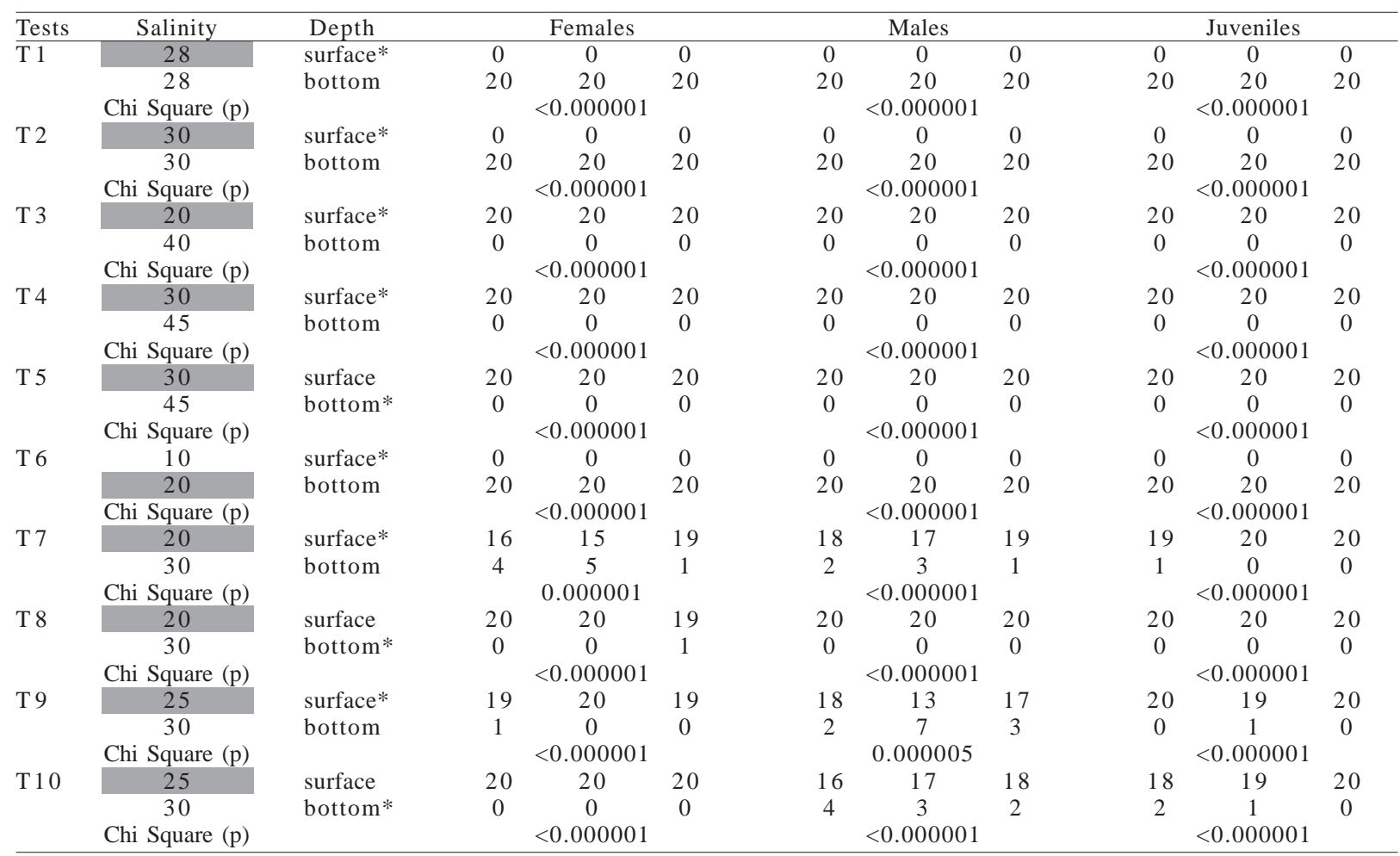


of the container, the individuals took 2 minutes to reach the surface, where they remained until the end of the test $(\mathrm{p}<0.001)$ (Tab. III).

In the test T6, with lower salinities in the surface and bottom (10-20), all the mysids migrated to the bottom after been released at the surface $(p<0.001)$ (Tab. III). However, when salinities were increased (T7 to T10), but with differences between surface and bottom lower than 10 (20-30 and 25-30), the animals tended to remain in the surface, avoiding higher salinities of the bottom $(\mathrm{p}<0.001)$. Nevertheless, unlike the other tests performed, there was no $100 \%$ response, with few individuals been observed migrating to the bottom with no relation to releasing place or acclimatizing salinity (Tab. III).

In the tests T11 to T15, performed in dark, the adults (males and females) migrated to the surface $(\mathrm{p}<0.011)$, while the juveniles from tests T13 and T14, with a gradient salinity of 25-30, stayed on the bottom, even if released in the surface. The juveniles from test 11 , performed in salinity 28 and with no gradient in this parameter also migrated to the bottom of the container (Tab. IV). The tests T16 to T19, where temperature was tested as a significant factor $\left(20-30^{\circ} \mathrm{C}\right.$ e $25-30^{\circ} \mathrm{C}$ ), showed that the mysids always searched for the bottom, even if released in the surface or not (Tab. V).

\section{DISCUSSION}

The high survival of $M$. e. atlantica during the acclimation period indicates that the acclimatizing protocol was effective for this particular species. It is important to mention that the applied acclimatizing procedure (reductions of 5 parts at each 4 hours) was less sharp than the adopted by WEBB et al. (1997), who during the acclimatizing of Gastrosaccus brevifissura Tattersall, 1952 reduced the salt concentration from 21 to 15 in just three hours.

In the assays performed under same salinity and temperature during the day, the vertical migration to the bottom observed was in agreement with the pattern suggested in the literature, which describes it as a general behavior of the mysids, which stand on the bottom during the daylight and migrate upwards during the night to feed on phyto and zooplankton (ALLEN, 1982; BEETON \& BOWERS, 1982; Rudstman et al., 1989; McKenney \& Celestial, 1995; TAKAHASHI \& KaWAGUCHI, 1997; BUSKEY, 1998; ROAST et al., 1998; Calliari et al., 2001; Viherluoto \& VitTASAlo, 2001; HAMPEl et al., 2003; SCHARF \& KosCHEL, 2004; ANOKHINA, 2005).

A different result was observed during the daylight assays with the presence of a marked halocline and high salinity at the bottom (20-40 and 30-45). When too high salinities were observed near the bottom, the organisms remained at the surface or searched for it when released on the bottom. This behavior indicates that the species avoids higher salinities, even when its primary behavior is to search for the bottom of the container. Nevertheless,

Table IV. Salinity tests using females, males and juveniles of Metamysidopsis elongata atlantica (Bascescu, 1968) ( $\mathrm{n}=20$ ) performed at temperatures of $25 \pm 1{ }^{\circ} \mathrm{C}$ under dark conditions, where the number with the asterisk represents the place where individuals were released and the grey area is the acclimation salinity.

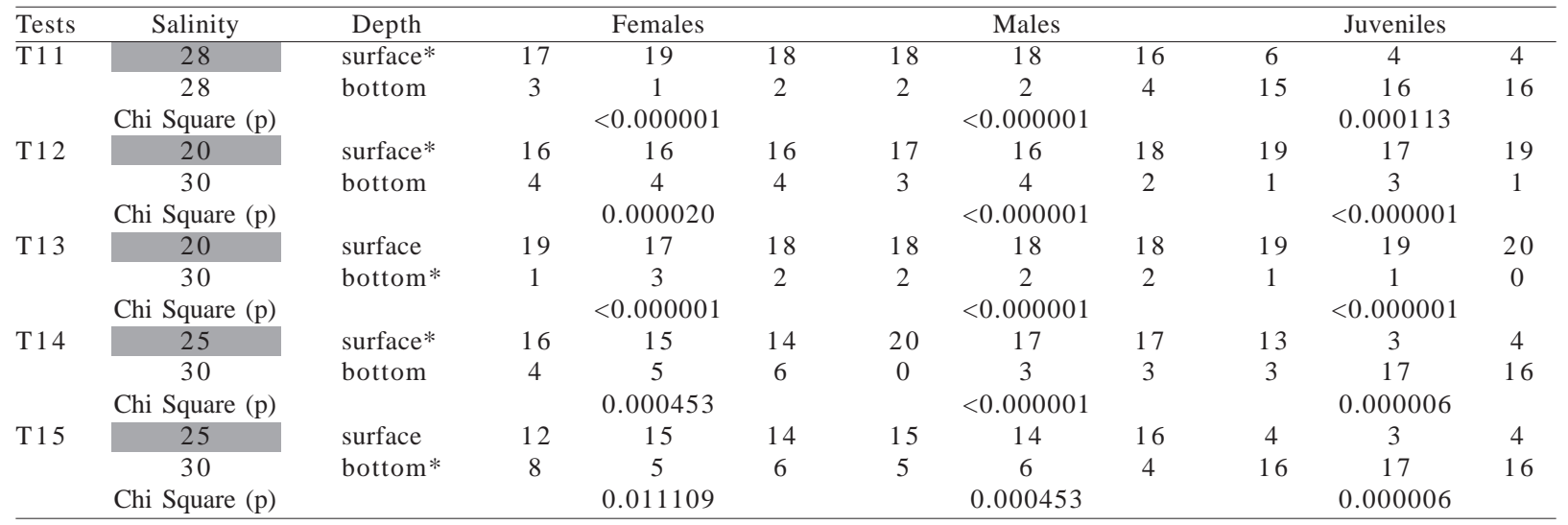

Table V. Temperature tests using females, males and juveniles of Metamysidopsis elongata atlantica (Bascescu, 1968) (n=20) performed at salinity $20 \pm 1$ under room light, where the number with the asterisk represents the place where individuals were released and the grey area is the acclimation salinity.

\begin{tabular}{|c|c|c|c|c|c|c|c|c|c|c|c|}
\hline Tests & Temperature & Depth & \multicolumn{3}{|c|}{ Females } & \multicolumn{3}{|c|}{ Males } & \multicolumn{3}{|c|}{ Juveniles } \\
\hline \multirow[t]{3}{*}{ T16 } & 30 & surface* & 1 & 1 & 2 & 1 & 3 & 0 & 0 & 0 & 0 \\
\hline & 20 & bottom & 19 & 19 & 18 & 19 & 17 & 20 & 20 & 20 & 20 \\
\hline & Chi Square (p) & & \multicolumn{3}{|c|}{$<0.000001$} & \multicolumn{3}{|c|}{$<0.000001$} & \multicolumn{3}{|c|}{$<0.000001$} \\
\hline \multirow[t]{3}{*}{$\mathrm{T} 17$} & 30 & surface & 2 & 1 & 0 & 0 & 1 & 0 & 0 & 0 & 0 \\
\hline & 20 & bottom* & 18 & 19 & 20 & 20 & 19 & 20 & 20 & 20 & 20 \\
\hline & Chi Square (p) & & \multicolumn{3}{|c|}{$<0.000001$} & \multicolumn{3}{|c|}{$<0.000001$} & \multicolumn{3}{|c|}{$<0.000001$} \\
\hline \multirow[t]{3}{*}{$\mathrm{T} 18$} & 20 & surface* & 3 & 2 & 3 & 3 & 4 & 2 & 4 & 2 & 3 \\
\hline & 15 & bottom & 17 & 18 & 17 & 17 & 16 & 18 & 16 & 18 & 17 \\
\hline & Chi Square (p) & & \multicolumn{3}{|c|}{$<0.000001$} & \multicolumn{3}{|c|}{$<0.000001$} & \multicolumn{3}{|c|}{$<0.000001$} \\
\hline \multirow[t]{3}{*}{ T 19} & 20 & surface* & 3 & 2 & 1 & 2 & 2 & 3 & 4 & 6 & 6 \\
\hline & 10 & bottom & 17 & 18 & 19 & 18 & 18 & 17 & 16 & 14 & 14 \\
\hline & Chi Square (p) & & \multicolumn{3}{|c|}{$<0.000001$} & \multicolumn{3}{|c|}{$<0.000001$} & \multicolumn{3}{|c|}{0.001114} \\
\hline
\end{tabular}


even when the difference in surface/bottom salinity was reduced to 20-30 and 25-30, simulating real conditions when ocean waters penetrates into the estuary, in the presence of room light, the individuals kept on looking for the surface even when released on the bottom.

However, when bottom salinity was reduced to 20 in the assay with 10-20 halocline, the animals searched for the bottom again, reproducing the behavior observed in constant salinities, presenting the standard behavior of remain in the bottom during the daylight.

In the assays performed under dark conditions, in salinities from 20-30 and 25-30, the adult organisms searched for the surface of the container, actively swimming to the lower salinity layer, either when released at the bottom, or remaining in the surface when released in this position.

In the assays performed under night conditions, with constant salinity in the water column, it was observed that the adults remained in the surface after been released. Unlike adults, juveniles searched for bottom at constant salinities (28) or with a halocline of 25-30, generating conflicting results with the observations registered under room light conditions. A similar behavior pattern was observed in the wild for Archaeomysis kokuboi Ii, 1964 and Archaeomysis japonica Hanamura \& Murano, 1996 at Otsuchi Bay in Japão (TAKAHASHI \& KAWAGUCHI, 1997; ANOKHINA, 2005). It is likely that juvenile of M. e. atlantica may present this downward movement as an strategy to avoid predation, since adults, as described earlier, migrate to the surface at night in the search for food, even predating juvenile of their own species (ANOKHINA, 2005).

With relation to temperature gradients $\left(30-20 \pm 1^{\circ} \mathrm{C}\right.$; $20-15 \pm 1^{\circ} \mathrm{C}$ e $20-10 \pm 1^{\circ} \mathrm{C}$ ), the mysids always moved to the bottom, in spite of the releasing site, in the same way as observed in the constant salinities. This result indicates that M. e. atlantica does not seem to be affected by the temperature gradients as observed in the wild (ANOKHINA, 2005).

The effects of temperature over juveniles of Neomysis americana Smith, 1874, a coastal and estuarine species from Florida, were analyzed in an attempt to test the role of these parameters on the distribution and life cycle of the organisms (PEZZACK \& COREY, 1982). In spite of been warm water organisms, a marked tolerance to temperature and salinity variation were recorded, in such a way that its distribution limits seems to be determined only by lethal values of these parameters.

Our results suggest that $M$. e. atlantica presents clear responses to environmental gradients. Andréa M. da S. Gama (unpublished data) identified that M. $e$. atlantica was caught with higher frequency during night samples in the estuarine area of Patos Lagoon, in conditions of increasing surface salinities and decreasing temperatures.

The surface occurrence during night periods is related to the behavior of upward movement in the water column widely recorded in the literature (ALLEN, 1982; BeEton \& Bowers, 1982; RudstMan et al., 1989; McKenney \& Celestial, 1995; TAKAhashi \& KaWAGUChi, 1997; Buskey, 1998; RoAst et al., 1998; CAllari et al., 2001; ViherLUOTO \& VitTASAlo, 2001; HAMPEl et al., 2003; Scharf \& Koschel, 2004; Anokhina, 2005). On the other hand, sarching for the surface with increasing salinities may evidence a behavioral pattern associated with the identification of a rising tide.

Estuarine animals are continuously struggling against strong downstream currents. Keeping position in the estuarine region implies swimming upstream or to take advantage of the tide currents to maintain position. The fact that this species searched for the surface with increasing salinities on the bottom may represent a behavioral response to keep horizontal position inside the estuarine area.

Mysids may control their position in the water column by swimming. Neomysis integer (Leach, 1814), a common species of the hyperbenthos from Looe River (Cornwall, England), uses its swimming capacity to keep its position in the water column (RoAst et al., 1998). Adults of Metamysidopsis elongata (Holmes, 1900) also actively swim to keep position in the water column, partially compensating the drift currents and tide (CLUTTER, 1967; 1969). Mesopodopsis slabberi (van Beneden, 1861) showed to be affected by changes in the gradient of salinity in the estuary of Tamar (England); MOFFAT \& JONES (1993), using circulation layers to keep its position inside the estuary and actively migrating to the higher salinity regions when necessary. Neomysis mercedis Holmes, 1897 inhabiting the Delta Bay (São Francisco, USA) also uses bottom and surface currents as a mechanism to regulate its position (MOFFAT \& JONES, 1993).

Behavioral responses of $M$. e. atlantica to salinity assays corroborate the hypothesis that this species also takes advantage of environmental information as a mechanism to maintain the horizontal position in the estuarine zone. When the bottom salinities in the estuary are above 30 and the surface salinity is above 20, it is clearly taking place an influx of marine water. Considering a possible oceanic origin of this species, since according to A. M. da S. Gama (unpublished data), this species was more frequently caught in salinities around 34, in searching for surface waters $M$. e. atlantica would increase the chances of returning to the sea. Even if this tidal movement is taking place during the daylight, it would be convenient to the animals abandon the bottom to avoid the involuntary migration farther into the estuarine area.

Acknowledgments. To Dr. Elis Regina Lopes Leitzke for her constructive suggestions and to MSc. Alessandro Pereira Cardozo for the support during the assays in the laboratory.

\section{REFERENCES}

Allen, D. M. 1982. Autoecology of the cryptic mysid crustacean, Heteromysis formosa S. I. Smith 1873, in a temperate estuary. Hydrobiogia 93:1-7.

Almeida-Prado, M. S. 1974. Sistemática dos Mysidacea (Crustacea) na região de Cananéia. Bulletin Institute Oceanographic 23:47-87.

Anokhina, L. L. 2005. Seasonal dynamics of diel changes in inshore bathypelagic communities of the Black Sea by the example of the Golubaya Bay (Gelendzhik Town). Biology Bulletin 32(3):288-300.

AstThorsson, O. S. \& RALF, R. 1984. Growth and moulting of Neomysis integer (Crustacea: Mysidacea). Marine Biology 79:55-61.

Beeton, A. M. \& Boowers, J. A. 1982. Vertical migration of Mysis relicta Lovén. Hydrobiologia 93:53-61.

Bhattacharya, S. S. 1982. Salinity and temperature tolerance of juvenile Mesopodosis orientalis: laboratory studies. Hydrobiologia 93:23-30.

Brown, A. C. \& MCLaChlan, A. 1990. Ecology of sandy shores. Amsterdam, Elsevier. 328p.

Buskey, E. J. 1998. Energetic cost of position-holding behavior in the plankton mysid Mysidiun columbiae. Marine Ecology Progress Series 172:139-147.

Calliari, D.; Cervetto, G. \& Gomes, M. 2001. Short-term variability in abundance and vertical distribution of the opossum shrimp Neomysis Americana in the Solis Grande River Estuary, Uruguay. Atântica 23:117-125. 
Calliari, D.: Cervetto, G. \& Rodrigues, L. 2007. Salinity preferences and habitat partitional between dominant mysids at the Río de la Plata estuary (Uruguay). Journal of Marine Biological Association of the United Kingdom 87:501-506.

Cervino, C. O.; Luquet, C. M.; Haut, G. E. \& Rodriguez, E. M. 1996. Salinity preferences of the estuarine crab Chasmagnatus granulata Dana, 1851 after long-term acclimation to different salinities. Atlântica 18:69-75

Chung, K. S. 2001. Ecophysiological adaptability of tropical water organisms to salinity. Revista de Biologia Tropical 49(1):9-13.

Clutter, R. I. 1967. Zonation of nearshore mysids. Ecology 48:200-208.

1969. The microdistribution and social behavior of some pelagic mysid shrimps. Journal of Experimental Marine Biology and Ecology 69(1):93-115.

Du Preez, H. H.; Mclachlan, A.; Marias, J. K. F. \& Cockroft, A. C. 1990. Bioenergetics of fishes in a high-energy surf-zone. Marine Biology 106:1-12.

Gama, A. M. S.; Montú, M. A. \& D’Incao, F. 2006. Ciclo de mudas e taxas de crescimento de Metamysidopsis elongata atlantica (Crustacea, Mysidacea) cultivado em diferentes temperaturas e salinidades. Iheringia, Série Zoologia, 96(1):67-70.

Gama, A. M. S.; Montú, M. A. \& Gusmão, L. F. M. 2002. Ciclo de vida pós-marsupial e crescimento de Metamysidopsis elongata atlantica (Crustacea, Mysidacea, Mysidae) em cultivo de laboratório. Iheringia, Série Zoologia, 92(1):77-83.

Gama, A. M. S. \& Zamboni, A. J. 1999. Aspectos da biologia e do cultivo de Metamysidopsis elongata atlantica para uso em testes de toxicidade. Nauplius 7:127-139.

Gross, W. J. 1957. A behavior mechanism for osmotic regulation in a semi terrestrial crab. Biological Bulletin 113:268-274.

Hampel, H.; Cattrissse, A. \& VincX, M. 2003. Tidal, diel and semilunar changes in the faunal assemblage of an intertidal salt marsh creek. Estuarine Costal and Shelf Science 56:795-805.

Hesthagen, I. H. 1973. Diurnal and seasonal variations in the near-bottom fauna the hyperbenthos in one of the deeper channels of the Kierler Bucht (western Baltic). Kieler Meeresforschungen 29:116-140.

Hough, A. R. \& NAYlor, E. 1992. Distribution and position maintenance behavior of the estuarine mysid Neomysis integer. Journal of Marine Biological Association 72(4):869-876.

Jerling, H. L. \& Wooldridge, T. H. 1995. Feeding of two mysid species on plankton in temperate South African estuary. Journal of Experimental Marine Biology and Ecology 188:243-259.

LASIAK, T. A. 1981. Nursery grounds of juvenile teleosts: evidence from a surf zone of King's Beach, Port Elizabeth. South African Journal of Science 77:388-390.

Lasiak, T. A. \& McLachlan, A. 1987. Opportunistic utilization of mysid shoals by surf-zone teleosts. Marine Ecology Progress Series 37:1-7.

Lopes, R. M.; Montú, M. A.; Gorri, C.; Muxagata, E.; Miyashita, L. K. \& Oliveira, L. O. 2006. Zooplâncton marinho na região entre o Cabo de São Tomé (RJ) e o Chuí (RS). In: RossiWoongtschowski, C. L. D. B. \& Madureia, L. S. P. eds. O Ambiente Oceanográfico da Plataforma Continental e do Talude na Região Sudeste-Sul do Brasil. São Paulo, Edusp. p.265-358

Luque, C. M.; Ford, M.; Rodriguez, E. M.; Ansaldo, M. \& Stella, V. 1992. Ionic regulation patterns in two species of estuarine crabs. Comunicaciones Biologicas 10:315-325.

Mauchline, J. 1971. The Biology of Neomysis integer (Crustacea: Mysidacea). Journal of Marine Biological Association of the United Kingdom 51:347-354.

1980. The biology of mysids and euphausiids. In: Blaxter, J.

H. S.; Russel, F. S. \& Yonge, M. eds. Advances in Marine Biology. London, Academic. v.18, p.1-369.

McKenney, C. L. \& Celestial, D. M. 1995. Interactions among salinity, temperature and age on growth of the estuarine Mysid: Mysidopsis bahia reared in the laboratory throw a complete life cycle. Body mass and age-specific growth rate. Journal of Crustacean Biology 15(1):169-178

McLachlan, A. 1983. Sandy beach ecology - a review. In: Mclachlan, A. \& Erasmus, T. eds. Sandy beaches ecosystems. The Hague, Boston, London, Junk. p.321-380. 1990. Surf zone fauna. In: Brown, A. C. \& McLachlan, A. eds. Ecology of Sandy Shores. Amsterdam, Elsevier. p.321-380. Miller, G. S. 2003. Mysis vertical migration in Grand Traverse
Bay, Lake Michigan, observed by an acoustic Doppler current profiler. Journal Great Lakes Research 29(3):427-435.

Moffat, A. M. \& Jones, M. B. 1993. Correlation of the distribution of Mesopodopsis slabberi (Crustacea: Mysidacea) with physico-chemical gradients in a partially-mixed estuary (Tamar, England). Netherland Journal Aquatic Ecology 27(2-4):155-162

O'Brien, D. P. O.; Tay, D. \& Zwart, P. R. 1986. Laboratory method of analysis of swarming behavior in macroplankton: combination of a modified flume tank and stereophotographic techniques. Marine Biology 90:517-227.

Pastorino, M. R.; Antunes, C. P.; Marques, J. R.; Pereira, M. L.; Azeiteiro, U. M. M. \& Morgado, M. F. 2003. Histochemistry and histology in planktonic ecophysiological processes determination in a temperature estuary (Mondego Rive estuary, Portugal). Acta Oecologica 24:253-243.

Pezzack, D. S. \& Corey, S. 1982. Effects of temperature and salinity on immature and juvenile Neomysis americana (Smith) (Crustacea: Mysidacea). Canadian Journal Zoology 60:2725-2728.

Roast, S. D.; Widdows, J. \& Jones, M. B. 1998. The position maintenance behavior of Neomysis integer (Peracarida: Mysidacea) in response to current velocity, substratum and salinity. Journal of Experimental Marine Biology and Ecology 220:25-45

Rudstam, L. G.; Danielsson, S.; Hansson, S. \& Johansson, S. 1989. Diel vertical migration and feeding patterns of Mysis mixta (Crustacea: Mysidacea) in the Baltic Sea. Marine Biology 101:43-52.

SCHARF, J. \& Koschel, R. 2004. Distribution, abundance and life history of Mysis relicta (Lovén) in the Feldberg Lake District, Germany. Limnology 34:199-212.

SChlacher, T. A. \& Wooldridge, T. H. 1994. Tidal influence on distribution and behavior of the estuarines opssum shrimp Gastrosaccus brevissura. In: DYER, K. R. \& ORTH, R. J. eds. Change in fluxes in estuaries: implications from science to management. Fredensborg, Olsen and Olsen. p.307-312

Signoret, G. P. B. \& Brailovsky, D. S. 2004. Adaptive Osmotic Responses of Macrobrachium Acanthurus (Wiegmann) and Macrobrachium Carcinus (Linnaeus) (Decapoda, Palaemonidae) Bulletin Academic Publishers of Gulf of México 77(4):455-465

Steven, D. M. 1961. Shoaling behavior in a mysid. Nature 192: 280,281

Takahashi, K.; Hirose, T.; Azuma, N. \& Kawaguchi, K. 2004. Diel and intraspecific variation in vulnerability of the beach mysid, Archaeomysis kokuboi, to fish predators. Crustaceana, 77:717-728

Takahashi, K. \& Kawaguchi, K. 1997. Diel and tidal migrations of the sand-burrowing mysids, Archaeomysis kokuboi, A. japomica and Iella ohshimai in Otsuchi Bay, northeastern Japan. Marine Ecology Progress Series 148:95-107.

Viherlouto, M. \& Vittasalo, M. 2001. Effect of light on the feeding rates of pelagic and littoral mysid shrimps: a trade-off between feeding success and predation avoidance. Journal of Experimental Marine Biology and Ecology 261:237-244.

Vittasalo, M. \& Rautio, M. 1998. Zooplanktivory by Praunus ûexuosus (Crustacea: Mysidacea): functional responses and prey selection in relation to prey escape responses. Marine Ecology Progress Series 174:77-87.

Warman, C. G.; O’Hare, T. J. \& Naylor, E. 1991. Vertical swimming in wave-induced currents as a control position mechanism of intertidal migration by a sand-beach isopod. Marine Biology 111:49-54.

Webb, P.; Wooldridge, T. \& Schlacher, T. 1997. Osmoregulation and spatial distribution in four species of mysid shrimps. Comparative Biochemistry Physiology 117A(4):427-431.

Williams, R. \& Collins, N. R. 1984. Distribution and variability in abundance of Schistomysis spiritus (Crustacea: Misidacea) in the Bristol Channel in relation to environmental variables, with comments on other mysids. Marine Biology 80:97-206.

WitTMANN, K. 1977. Modification of association and swarming in north Adriatic Mysidacea in relation to habitat and interacting species. In: Keegnan, B. F.; Ceidigh, P. O. \& Boaden, P. S. J. eds. Biology of Benthic Organisms. Oxford, Pergamon. p.605-612. WoOlDRIDGe, T. 1983. Ecology of beach and surf-zone mysid shrimps in the Eastern Cape, South Africa. In: McLachlan, A. \& Erasmus, T. eds. Sandy beaches ecosystems. The Hague, Boston, London, Junk. p.321-380.

Recebido em novembro de 2010. Aceito em abril de 2011. ISSN 0073-4721

Artigo disponível em: www.scielo.br/isz 